\title{
Effects of different protein sources of diet on yield and quality of lamb meat
}

\author{
D. Ružić-Muslic ${ }^{1 \star}$, M. P. Petrovic ${ }^{1}$, M. M. Petrovic ${ }^{1}$, Z. Bijelic ${ }^{1}$, V. Pantelic ${ }^{1}$ and P. Perišic ${ }^{2}$ \\ ${ }^{1}$ Institute for Animal Husbandry, Autoput 16, 11080 Zemun-Belgrade, Serbia. \\ ${ }^{2}$ Faculty of Agriculture, Belgrade, Serbia. \\ Accepted 18 July, 2011
}

\begin{abstract}
The results obtained in the study of the effects of different protein sources in diet on fattening parameters, yield and quality of meat from weaned lambs are presented in this study. Experiment was conducted on 60 lambs of MIS population, weaned at the age of 60 days and divided into three groups. The effect of use of three concentrate mixtures which differed in regard to protein source: sunflower meal (I), soybean meal (II) and fish meal (III), was studied. Average daily gain of lambs on treatments I, II and III was: $0.169,0.205$ and $0.227 \mathrm{~kg}$. Conversion of dry matter (kg/kg gain) on analogue treatments was: 4.54, 3.71 and 3.30; of energy (MJ NEM/ $\mathrm{kg}$ ): 33.77, 29.37 and 26.25; of total proteins (g/kg): 732,596 and 549; of PDIN (g/kg): 502, 414 and 381; of PDIE (g/ $/ \mathrm{kg}): 480,425$ and 396 . Values of the yield of warm carcass with offal according to treatments I, II and III were: $58.70,58.02$ and $57.42 \%$. Share of I category meat on analogue treatments was: $37.27,37.35$ and $37.51 \%$, meat of II category: $33.9,32.67$ and $32.83 \%$, whereas meat of III category was present in the following percentages $27.78,29.59$ and $29.10 \%$. Surface of MLD in lambs on treatments I, II and III was: $11.47,13.09$ and $13.86 \mathrm{~cm}^{2}$. With regards to chemical and technological parameters of MLD, as well as morphological composition of carcass side, no significant difference between investigated treatments were established $(P>0.05)$.
\end{abstract}

Key words: Lambs, protein source, gain, yield, meat quality.

\section{INTRODUCTION}

Active population of micro-organisms in rumen of ruminants degrade the protein from the diet to peptides, amino acids and ammonia, and subsequently these substances are used in the synthesis of their own proteins. During each of these degradation and synthesis processes, certain losses occur (usually about 20\%), which means that due to the action of micro-organisms, reduced quantity of amino acids reaches the location of digestion and protein adoption (Grubic et al., 1992).

${ }^{\star}$ Corresponding author. E-mail: muslic.ruzic@.gmail.com. Tel: +381112670121. Fax: +381112670164.

Abbreviations: MIS, Meat sheep breed of the Institute for Animal Husbandry; RUP, rumen undegradable protein; CP, crude protein; Protein source: I, sunflower meal; II, soybean meal; III, fish meal; PDIN, protein digested in small intestine depending on the fermenting of nitrogen; PDIE, protein digested in small intestine depending on the fermenting of organic matter.
In order to ensure the optimal pool of amino acids for certain production, it is necessary to provide in diet, for lambs, protein fraction which avoids degradation in rumen (non-degradable protein), which is achieved, inter alia, using different protein sources (Ruzic-Muslic, 2006). With the increase of genetic capacities of lambs, also their requirements increase, especially in proteins which pass through stomach and are not non-degraded, and together with microbial protein that get to the duodenum, since microbiological synthesis of proteins from common sources of nitrogen and energy cannot satisfy the needs of such animals in regard to proteins (Shahrbabak et al., 2009; Hussein et al., 1991; Grubic et al., 1992).

Considering this, the objective of this study was to investigate the effect of different protein sources on yield and quality of meat from intensively fattened lambs.

\section{MATERIALS AND METHODS}

Feeding trial included 60 lambs of MIS population, weaned at the age of 60 days and divided into three homogenous groups. MIS 
Table 1. Composition of concentrate mixtures for fattening of weaned lambs (\%).

\begin{tabular}{lccc}
\hline \multirow{2}{*}{ Feed } & \multicolumn{3}{c}{ Concentrate mixture } \\
\cline { 2 - 4 } & I & II & III \\
\hline Corn & 73 & 79 & 82 \\
Sunflower meal & 23 & 5 & 7 \\
Soybean meal & 0 & 12 & 0 \\
Fish meal & 0 & 0 & 7 \\
Livestock lime & 2 & 2 & 2 \\
Salt & 1 & 1 & 1 \\
Premix & 1 & 1 & 1 \\
\hline
\end{tabular}

Protein source: I, sunflower meal, II, soybean meal and III and fish meal.

Table 2. Nutritional value of mixtures.

\begin{tabular}{|c|c|c|c|}
\hline \multirow{2}{*}{ Nutritional indice } & \multicolumn{3}{|c|}{ Concentrate mixture } \\
\hline & I & II & III \\
\hline Dry matter $\left(\mathrm{g} \mathrm{kg}^{-1}\right)$ & 870 & 860.5 & 860.8 \\
\hline OFU * & 1.2 & 1.2 & 1.2 \\
\hline $\mathrm{NEM}^{*}(\mathrm{MJ})$ & 7.51 & 7.98 & 7.91 \\
\hline $\mathrm{UFV}^{* *}$ & 0.99 & 1.05 & 1.04 \\
\hline Total protein* $(\mathrm{g} / \mathrm{kg})$ & 142 & 137 & 141 \\
\hline RUP & 43 & 51 & 58 \\
\hline PDIN/g/animal/day** & 102 & 103 & 107 \\
\hline PDIE/g/animal/day** & 102 & 112 & 118 \\
\hline Ashes* & 25 & 23 & 27 \\
\hline $\mathrm{Ca}^{*}(\mathrm{~g})$ & 8.4 & 8.2 & 10.6 \\
\hline$P^{*}(g)$ & 4.6 & 3.7 & 5.0 \\
\hline
\end{tabular}

Protein source: I, sunflower meal; II, soybean meal and III, fish meal; RUP, rumen undegradable protein; PDIN, protein digested in small intestine depending on the fermenting nitrogen; PDIE, protein digested in small intestine depending on the fermenting organic matter. ${ }^{*}$ INRA (1988); ${ }^{*}$ Obračevic (1990).

sheep is a new population created in the experimental sheep farm of the Institute for Animal Husbandry, Zemun-Belgrade, Serbia by complex crossing of three sheep breeds. Maternal basis was Pirot Pramenka breed, rams of Merinolandschaf breed were used, and as terminal breed, lle de France rams were used. MIS is the meat type of sheep that strongly constitute carcass conformation and exceptional meat properties (Petrovic, 2006). Average body mass of lambs at the beginning of trial was approximately $18.0 \mathrm{~kg}$. Nutrition of lambs with livestock mixtures and hay was grouped and ad libitum, alfalfa hay was restricted to $250 \mathrm{~g} /$ animal/day. Studied mixtures (3) differed with regards to protein source: sunflower meal (diet type I), soybean meal (diet type II) and fish meal (diet type III). Body mass of lambs in trial was determined by measuring with 15 day intervals. Feed conversion was calculated based on realized gain and consumption/use of food between two measurement as well as for the total trial period. Calculation of nutritional value was done based on French system recommended by INRA (1988) and Obračevic (1990). Composition of mixtures is presented in Table 1, and their nutritional value is shown in Table 2.

At the end of the trial, in order to determine the yield and quality of meat, 18 animals were selected randomly (6 animals from each treatment), slaughtered and treated in the regular way in the experimental slaughterhouse of the institute for Animal Husbandry. After a cooling period of $24 \mathrm{~h}$ at the temperature of 0 to $+4^{\circ} \mathrm{C}$, mass of cooled carcasses with the head and offal was determined, also, carcasses were cut into two symmetrical carcass sides along the spinal line. Left carcass side was cut into main parts according to the method laid down in the Regulation on Cutting and Categorization of Sheep Meat (Official Journal of SFRY, No. 34 from 1974).

At the intersection between 12th and 13th rib, imprint was taken from the cross section of Musculus longissimus dorsi (MLD) on transparent tracing paper. Surface of the cross section was measured planimetrically.

In the chemical analysis of MLD samples, the following was determined: content of total water in meat (\%), by drying samples in a dryer at the temperature of $105^{\circ} \mathrm{C}$; content of intramuscular fat, by ether extraction in Soxhlet apparatus; content of total nitrogen matters, using the micro-method according to Kjeldahl and content of ashes, by burning samples at a temperature of $550^{\circ} \mathrm{C}$ to constant mass.

Of the major technological properties of meat, the following were determined: loss of mass in heat treatment- cooking (10 min at $90^{\circ} \mathrm{C}$ ) and roasting $\left(8 \mathrm{~min}\right.$ at 190 to $\left.200^{\circ} \mathrm{C}\right)$, that is, cooking loss and roasting loss.

The ratio of tissues in the carcass side (morphological composition) was studied in the three rib cut (9th, 10th and 11th rib) by dissection and measurement of the muscle, fat, bone and 
Table 3. Production results of fattening lambs.

\begin{tabular}{lccc}
\hline \multirow{2}{*}{ Indicator } & \multicolumn{3}{c}{ Diet type } \\
\cline { 2 - 4 } & I & II & III \\
\hline Body mass of animal at the beginning of trial $(\mathrm{kg})$ & 18.12 & 18.08 & 18.17 \\
Age at the beginning of trial (days) & 60 & 60 & 60 \\
Body mass of animal at the end of trial $(\mathrm{kg})$ & 30.78 & $33.52^{* *}$ & $35.17^{* * *}$ \\
Total gain $(\mathrm{kg})$ & 12.70 & $15.40^{* *}$ & $17.00^{* *}$ \\
Average daily gain $(\mathrm{kg})$ & 0.169 & $0.205^{* *}$ & $0.227^{* *}$ \\
\hline
\end{tabular}

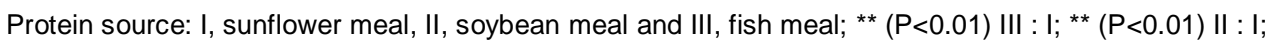

$(P>0.05)$ III : II.

connective tissue.

Statistical processing of the obtained data was done on PC using program Stat.Soft, Inc. (2003) STATISTICA (data analysis software system), version 6 and standard mathematical-statistical methods.

\section{RESULTS AND DISCUSSION}

Data on average production indicators according to treatments is presented in Table 3.

\section{Body mass and gain}

Source of protein in the diet had very significant effect $(P<0.01)$ on the final fattening result expressed by average daily gain: 0.169 (I), 0.205 (II) and 0.227 (III) kg, and final body mass of trial animals: $30.78 \mathrm{~kg}(\mathrm{I}) ; 33.52$ $\mathrm{kg}$ (II) and $35.17 \mathrm{~kg}$ (III). It is known that in ruminants, rumen micro-population degrades protein from the diet into peptides, amino acids and ammonia, and subsequently these substances are used for the synthesis of their own proteins. During each of these degradation and synthesis processes, certain losses occur (usually about $20 \%$ ), which means that due to the action of micro-organisms, reduced quantity of amino acids reach the location of digestion and protein adoption. If the degradation volume is greater, proportionally, the quantity of amino acids which directly remains for the animal is smaller (Grubic et al., 1992). Specific role of absorbed amino acids from small intestines in lambs is protein synthesis which contributes to tissue growth. This is especially important in intensive fattening of weaned lambs which have high genetic growth capacity. In other words, feeds containing proteins which pass through reticulum rumen, non-degraded and reach duodenum, such as fish meal, result to higher gains in lambs. These results are consistent with other researchers (Orskova et al., 1971; Miller, 1978; Grubic et al., 1991; Walz et al., 1998; Peter et al., 2000; Memisi et al., 2002).

However, by comparing soy bean meal and fish meal (treatments I and III) as protein sources in mixtures for lambs, no significant difference was established $(P>0.05)$ with regards to production performances of lambs. Absence of more significant response of fish meal (as source of non-degradable protein) as compared to soy bean meal (as source of degradable protein) can be attributed to high content of corn grain in the diet. Nutrition with high level of corn grain in lambs is associated with decrease of $\mathrm{pH}$ in rumen, due to depression of degradation of soy bean protein, which is a consequence of reduced microbiological activity, considering unafavourable conditions for the activity of microorganisms. Similar results were obtained by Hussein and Jordan (1991) who compared the effects of partial and complete substitution of soy bean meal with fish meal, on production parameters in fattening lambs. Also, results which are in concordance with our results were obtained in the research by Atti et al. (2007), in comparison with the effect of fish meal (5 and 10\%) and soy bean (in mixtures) for fattening of lambs using fattening parameters, carcass characteristics and composition of subcutaneous fatty tissue, and it established that it is possible to substitute soy bean with fish meal, considering that the obtained differences in the investigated parameters were not under the effect of nutrition treatment $(\mathrm{P}>0.05)$.

\section{Consumption of food and nutritional substances}

Results pertaining to consumption of food and nutritional substances are presented in Table 4. The best conversion of DM was established in lambs fed diets with fish meal (III) where for $\mathrm{kg}$ of gain by $27.31 \%$, less DM was used as compared to other animals fed diet with sunflower meal (I), and by $11.05 \%$, less DM was used as compared to animals fed diet with soybean meal (II). Also, the lowest consumption of protein per unit of gain was established in lambs fed diet III which was consumed by 25 and $7.88 \%$, respectively, and fewer proteins as compared to animals fed diets I and II. With the increase of share of non-degradable proteins in total proteins, decrease in use of energy occurred by 4.4 to 7.5 MJ NEM for each $\mathrm{kg}$ of realized gain. Data on conversion of food and nutritional substances obtained in this study are in accordance with other reports 
Table 4. Consumption of food and nutritional substances per kilogram of gain of lambs.

\begin{tabular}{lccc}
\hline \multirow{2}{*}{ Feed } & \multicolumn{3}{c}{ Diet type } \\
\cline { 2 - 4 } & I & II & III \\
\hline Concentrate mixture, $\mathrm{kg} / \mathrm{kg}$ & 3.65 & 3.10 & 2.83 \\
Alfalfa hay, $\mathrm{kg} / \mathrm{kg}$ & 1.50 & 1.09 & 0.91 \\
$\mathrm{DM}, \mathrm{kg} / \mathrm{kg}$ & 4.54 & 3.71 & 3.30 \\
CP,g/kg & 732 & 596 & 549 \\
PDIN,g/kg & 502 & 414 & 381 \\
PDIE,g/kg & 480 & 425 & 396 \\
NEM,MJ/kg & 33.77 & 29.37 & 26.25 \\
\hline
\end{tabular}

Protein source: I, sunflower meal, II, soybean meal and III, fish meal; PDIN, protein digested in small intestine depending on the fermenting nitrogen; PDIE, protein digested in small intestine depending on the fermenting organic matter.

Table 5. Average values of carcass mass and yield.

\begin{tabular}{lccc}
\hline \multirow{2}{*}{ Indicator } & \multicolumn{3}{c}{ Diet type } \\
\cline { 2 - 4 } & I & II & III \\
\hline Lamb pre-slaughter mass $(\mathrm{kg})$ & $30.78 \pm 4.73$ & $33.52 \pm 4.99$ & $35.17 \pm 5.34$ \\
Warm carcass mass with offal $(\mathrm{kg})$ & $18.07 \pm 2.86$ & $19.45 \pm 3.02$ & $20.19 \pm 3.31$ \\
Warm carcass yield with offal $(\%)$ & $58.70 \pm 1.14$ & $58.02 \pm 1.65$ & $57.42 \pm 1.47$ \\
Cold carcass yield with offal $(\mathrm{kg})$ & $56.49 \pm 1.37$ & $55.97 \pm 1.78$ & $55.38 \pm 1.22$ \\
Cold carcass mass without offal $(\mathrm{kg})$ & $15.44 \pm 2.22$ & $17.21 \pm 2.40$ & $17.36 \pm 2.57$ \\
Cold carcass yield without offal $(\mathrm{kg})$ & $46.45 \pm 1.25$ & $46.14 \pm 1.72$ & $45.42 \pm 1.27$ \\
\hline
\end{tabular}

Protein source: I, sunflower meal, II, soybean meal and III, fish meal.

(Kozarovski, 1988; Grubic et al., 1991; Mekic, 1994), which have established that with the increase of share of non-degradable proteins in total proteins (which is most often achieved by using two different protein sources), the consumption of food and nutritional substances per kilogram of realized gain decreases.

\section{Slaughter results}

Average values of carcass mass and yield are presented in Table 5. Established differences in values of dressing percentage ranged within limits of random deviations $(P>0.05)$, which means that different protein sources in diets for lambs had no significant effect on the studied traits. However, it was obvious that lambs in treatment with fish meal had the highest body mass, and that the value of dressing percentage was insignificantly lower as compared to values of dressing percentage of lambs on diet types I and II.

It is known that the value of dressing percentage, in addition to other factors, is also under the influence of the fattening level and development of fat tissue. The quantity of internal fat tissue, kidney fat and peritoneum with mesenterium was higher in lambs with greater body mass. This "separable" fat tissue in pelvic, abdominal and thoracic cavity was not the integral part of the carcass, resulting to greater body mass, but also slighlty lower value of dressing percentage in lambs on treatment III. Obtained results are in accordance with the results of Sokarovski et al. (1988), who, in the investigation of the effect of different protein sources: powder milk (I) and fish meal (II) in diets for fattening lambs at the age of 21 to 112 days, established the following dressing percentage values in the studied treatments: $48.42 \%$ (I) and $48.41 \%$ (II). Also, the study of the effect of different ratios of nondegradable proteins $(41,50$ and $60 \%$ ) in total mass of diet, on fattening and slaughter results in lambs of genotype lle de France ( 88 days of age) was carried out by Mekic et al. (1999), and it indicated that different protein sources have no significant effect on the value of dressing percentage of warm carcass with offal, considering that the obtained values were: $54.16,56.54$ and $57.36 \%$.

According to data presented in Table 6, share of 1 category of meat (leg/thigh and loin) in the mass of left side carcass of lambs on treatments I, II, III was: 37.27, 37.35 and $37.51 \%$. Share of meat of category II (back, shoulder and neck) was: $33.19,32.67$ and $32.83 \%$. Relative share of meat of III category (breast with fore thigh, second thigh) was: $27.78,29.59$ and $29.10 \%$. So, investigated treatment had no effect on carcass side mass and share of certain categories of meat considering that established differences were not statistically 
Table 6. Yield of meat of different categories.

\begin{tabular}{lccc}
\hline \multirow{2}{*}{ Indicator } & \multicolumn{3}{c}{ Diet type } \\
\cline { 2 - 4 } & I & II & III \\
\hline Left carcass side $(\mathrm{kg})$ & $7.69 \pm 1.12$ & $8.63 \pm 1.27$ & $8.65 \pm 1.28$ \\
I category meat $(\%)$ & $37.27 \pm 2.68$ & $37.35 \pm 1.35$ & $37.51 \pm 2.11$ \\
II category meat $(\%)$ & $33.19 \pm 2.21$ & $32.67 \pm 1.68$ & $32.83 \pm 1.36$ \\
III category meat $(\%)$ & $27.78 \pm 2.71$ & $29.59 \pm 2.53$ & $29.10 \pm 2.35$ \\
\hline
\end{tabular}

Protein source: I, sunflower meal, II, soybean meal and III, fish meal.

Table 7. Chemical and technological properties of meat.

\begin{tabular}{lccc}
\hline \multirow{2}{*}{ Property } & \multicolumn{3}{c}{ Diet type } \\
\cline { 2 - 4 } & \multicolumn{1}{c}{ I } & II & III \\
\hline MLD surface $\left(\mathrm{cm}^{2}\right)$ & $11.47 \pm 3.0$ & $13.09 \pm 2.65$ & $13.86 \pm 4.08$ \\
Chemical composition (\%) & & & \\
Water & $75.11 \pm 1.10$ & $75.00 \pm 0.95$ & $75.00 \pm 0.85$ \\
Proteins & $21.46 \pm 1.19$ & $21.62 \pm 1.22$ & $21.77 \pm 0.96$ \\
Fat & $2.28 \pm 0.52$ & $2.16 \pm 0.45$ & $2.12 \pm 0.52$ \\
Mineral substances & $1.09 \pm 0.06$ & $1.09 \pm 0.06$ & $1.09 \pm 0.04$ \\
& & & \\
Technological properties (\%) & & & \\
Cooking loss & $18.78 \pm 1.47$ & $18.78 \pm 1.99$ & $19.00 \pm 1.37$ \\
Roasting loss & $30.01 \pm 3.01$ & $28.58 \pm 2.48$ & $29.78 \pm 2.79$ \\
\hline
\end{tabular}

Protein source: I, sunflower meal, II, soybean meal and III, fish meal.

significant $(P>0.05)$. This is in accordance with the statements of certain authors (McClelland et al., 1976; Butterfield, 1988; Petrovic, 2000; Shahrbabak et al., 2009) who point out that variability with regards to quality of meat greatly depends on the genotype and age at slaughtering.

Results of the study of surface, chemical and technological properties of Musculus longissimus dorsi (MLD) are presented in Table 7. Established differences between investigated treatments were not statistically significant $(P>0.05)$, but it was noticeable that the greatest surface of MLD was established in lambs fed diets with fish meal. Results of our research are in accordance with the results obtained by Beerman et al. (1986) who established that in lambs fed mixture containing fish meal as main protein component, MLD surface was $19.37 \mathrm{~cm}^{2}$, whereas in animals on treatment with soy bean meal it was $17.31 \mathrm{~cm}^{2}$. Also, Walz et al. (1998) investigated the effect of diet with $13.5 \%$ of CP without and with $3 \%$ of fish meal in the mixture, on characteristics of lamb carcasses, and established that the surface of MLD was $15.2 \mathrm{~cm}^{2}$ (on treatment with fish meal) and $14.2 \%$ (on treatment without fish meal). According to Orskov et al., (1971), for younger lambs, fish meal represents the best additional source of protein. This is due to very high ratio of proteins that are non-degradable at the level of rumen, as well as favourable amino acid composition of this feed.

Different sources of protein in concentrated mixtures for feeding of lambs had no significant effect on chemical composition and technological properties of MLD. It was confirmed that proteins, as a significant parameter of the quality of lamb meat, showed no high variability (Petrovic, 2000).

By comparing our results with data obtained by Jovanovic et al. (1985), who established in the study of the effect of different protein sources (sunflower meal, ureas and prodain) on chemical properties of MLD, that the water content on the mentioned treatments was: 75.35, 74.63 and $74.13 \%$; fat content: $4.40,3.98$ and $5.28 \%$, and protein content: 19.86, 19.59 and $19.51 \%$, certain concordance could be seen. Our results are also in accordance with the results obtained by Manso et al. (1998), as well as Wiese et al. (2003), who stated that there were no significant differences with regards to properties and chemical composition of carcasses derived from lambs fed diets with different protein sources (soy bean meal, meat flour, urea and lupine). Morphological composition of carcass side was determined according to tissue ratio in three rib sample, 
Table 8. Tissue ratio in three rib cut.

\begin{tabular}{lccc}
\hline \multirow{2}{*}{ Property } & \multicolumn{3}{c}{ Diet type } \\
\cline { 2 - 4 } & I & II & III \\
\hline Mass of three rib cut (g) & $245.67 \pm 4.39$ & $265.50 \pm 5.01$ & $275.53 \pm 5.28$ \\
Ratio of certain tissues (\%) & & & \\
Muscle & & & \\
Fat & $43.52 \pm 4.61$ & $42.27 \pm 1.80$ & $41.92 \pm 3.12$ \\
Bone & $26.68 \pm 6.68$ & $31.76 \pm 3.07$ & $30.68 \pm 4.42$ \\
Connective & $28.23 \pm 6.33$ & $25.06 \pm 3.14$ & $25.93 \pm 5.60$ \\
Meat bone ratio (muscle and fat tissue together) & $1.19 \pm 0.64$ & $0.93 \pm 0.52$ & $1.01 \pm 0.53$ \\
\hline
\end{tabular}

Protein source: I, sunflower meal, II, soybean meal and III, fish meal.

with values presented in Table 8 . Results of relative ratios of certain tissues in the three rib sample showed that protein sources in mixtures for nutrition of lambs had no statistically significant effect on morphological composition of carcass sides $(P>0.05)$. However, the most favourable meat bone ratio was determined in lambs on treatments with soy bean and fish meal. Lambs on treatment with sunflower meal had $0.4 \mathrm{~kg}$ lesser meat per $1 \mathrm{~kg}$ of bones as compared to lambs on treatment with soy bean meal, and by $0.3 \mathrm{~kg}$ lesser as compared to lambs on treatment with fish meal. These results are in accordance with the investigations carried out by Sokarovski et al. (1988) and Tahirovic and Masnic (1979).

Obtained results which pertain to carcass properties, as well as ratio of certain tissues (muscle, fat, bone and connective tissue) showed that they were not under the influence of feeding treatment, which is in accordance with the results of Atti et al. (2007). This is due to the fact that lambs had similar weights of empty carcass and carcass composition, considering that pre-slaughter masses are similar. These parameters mainly depend on pre-slaughter body mass (Colomer-Rocher and Espejo, 1972; Atti et al., 2003).

Based on this result, we can conclude that different protein sources had no effect on value of dressing percentage, yield of meat of different categories, surface, chemical and technological properties of MLD and morphological composition of carcass sides.

\section{Conclusion}

Based on the obtained results of this study of the effect of different protein sources in diet on yield and quality of meat from lambs in intensive fattening, the following can be concluded:

1. The highest average daily gain $(0.227 \mathrm{~kg})$ was realized by lambs fed diet containing fish meal.

2. The best feed conversion was realized by lambs fed diet III.
3. Values of warm carcass yield with offal, in lambs on treatments I, II and III were: $58.70,58.02$ and $57.42 \%$.

4. Investigated feeding treatment showed no significant effect on yield of meat of different categories.

5. Different protein sources had no effect on surface, chemical and technological properties of MLD of lambs. Meat bone ratio on treatments I, II and III was: 2.5:1, 2.9:1 and 2.8: 1 .

6. Different protein sources influenced fattening parameters in lambs, whereas the yield and quality of meat were not under the influence of the investigated feeding treatment.

\section{ACKNOWLEDGEMENT}

This research is part of the Project EVB: TR-31053 financial supported by Ministry of Science and Technological Development of the Republic of Serbia.

\section{REFERENCES}

Atti N, Ben Salem H, Priolo A (2003). Effects of polyethlene glycol in concentrate on feed block on carcass composition and offal weight of Barbarine lambs fed Acacia cyanophylla Lindl. foliage. Anim. Res., 52: 363-375.

Atti N, Mahouachi M, Rouissi H (2007). Effects of fish meal in lamb diets on growth performance, carcass characteristics and subcutaneous fatty acid composition. Options Mediterraneenes, Series A, No. 74.

Beerman H, Hogue DE, Fichelll VK, Dalrymple RH, Ricn AC (1986). Effects of cimaterol and fishmeal on performance, carcass characteristics and skeletal muscle growth in lambs. J. Anim. Sci., 62: 370-380.

Colomer-Rocher F, Espejo DM (1972). Influence du poids d abattage et du sexe sur les performances de boucherie des agneauh i ssus du crosement Manchegox. Rasa Aragonesa. Ann. Zootech., 21: 401414.

Grubic G, Adamovic M, Negovanovic D (1992). Protein degradability as criteria for diet composition in ruminant nutrition.Innovation in livestock production. X: 125-131.

Hussein HS, Jordan RM (1991). Fish meal as a protein supplement in finishing lambs diet J. Anim. Sci., 69: 2115-2122.

INRA (1988). Alimentation des bovins, ovins et caprins. Ed. R. Jarriqe, INRA, Paris, p. 471.

Jovanovic R, Krajinovic M, Ukpabi H, Petrovic M, Mesaros A, Mrdjanov S (1985). The effect of different sources of non-protein nitrogen (NPN) on production performance of lambs. Contemp. Agric., 33: 9-10: 419- 
429.

Kozarovski N (1988). The effect of degradability on protein nutritional value in nutrition of fattening lambs. Doctoral dissertation. Faculty of Agriculture, Novi Sad.

Manso T, Mantenconb AR, Giraldezb FJ, Lavinb P, Castroa T (1998). Animal performance and chemical body composition of lambs fed diets with different protein supplements. J. Anim. Sci., 79(5): 13221328.

Mekic C (1994). Study of the reproductive and productive traits of lle de France sheep. Doctoral dissertation. Faculty of Agriculture, Belgrade.

Mekic C, Grubic G, Petrovic PM, Stojkovic M, Radovic M (1999). The effect of protein source on yield and quality of meat of lle de France lambs. Contemp. Agric., 48: 1-2: 237-244.

Memisi N, Bauman F, Grubic G, Koljajic V, Pavlov B (2002). The effect of different sources of non-degradable protein in diet on production performance of early weaned lambs in fattening. Biotechn. Anim. Husb., 18: 5-6, 213-219.

Miller EL (1978). Evaluating the protein contribution of feedsuffs for ruminants. Tech. Bull. No 5, IA FMM.

Obračevic (1990). Tables of nutritive value of livestock feed in the diet of ruminants, Scientific Book, Beograd.

Orskov ER, Mcdonald I, Fraser C, Corse EL (1971). The nutrition of the early weaned lamb. III The effect of ad libitum intake of diets varying in protein concentration on performance and on bory composition at differenty live weights, Cambridge. J. Agric. Sci., 77: 351-361.

Peter S, Erickson B, Barton A (2000). Whole soybeans for market lambs. J. Anim. Sci., 1249-1270.

Petrovic PM (2000). Genetics and breeding of sheep, Naučna, Beograd, p. 365.

Petrovic M (2006). Creation of meaty sheep breed MIS sheep. Institute for Animal Husbandry, Belgrade, p. 43.
Ruzic-Muslic D (2006). The effect of different protein sources in diet on production results of fattening lambs. Doctoral thesis, p. 160.

Shahrbabak SM, Rozbahan Y, Shahrbabak Moradi M, Shahrbabak Moradi H (2009). Influence of different levels of digestible undegradable protein on the carcass characteristic of Kermani male lambs in Iran.Intern. J. Agric. Biol., 11: 643-646.

StatSoft, Inc. (data analysis software system), version 6 (2003) www.statsoft.com.

Sokarovski J, Tokovski N, Jordanoski N (1988). The effect of genetic and nutrititive factors on production traits and carcass quality of early weaned and intensively fattened lambs. Forages, 30(7-8): 129-137.

Tahirovic M, Masnic H (1979). Fattening results of male Domestic Pramenka lambs fed concentrate mixtures with different protein sources. Conference on problems in livestock production of hillymountainous regions of Yugoslavia, pp. 375-385.

Walz LS, White TW, Fernandez JM, Gentry LR, Blourn DC, Froatschel MA, Brown TF, Lupton CJ, Chapa AM (1998). Effects of fish meal and sodium bentonite on daily gain, wool, growth, carcass characteristics and ruminal and blood characteristics of lambs fed concentrate diets. J. Anim. Sci., 76: 2025-2031.

Wiese SC, White CL, Masters DG, Milton JTB, Davidson RH (2003). Growth and carcass characteristics of prime lambs fed diets containing urea, lupins or canola meal as a crude protein source. Aust. J. Exp. Agric., 43: 1193-1197. 